\title{
The influence of applying a layer of carbon nanotubes on the piston bearing surface on friction losses
}

\begin{abstract}
The paper presents results of testing the resistance to motion of pistons whose bearing surface was coated with a layer of carbon nanotubes (CNTS). A part of this paper was devoted to the problems of applying a layer of nanotubes on the surface of an aluminum alloy, which is the most common material used for pistons. Obtaining a layer of nanotubes of a very narrow margin of tolerance was a difficult technological problem to overcome. A standard process of growing a layer of nanotubes leads to corrosion damage of the side surface of pistons; therefore, new technologies were developed which allow for obtaining a permanent layer of nanotubes less than 5 microns thick. Pistons with the bearing surface coated with a layer of nanotubes were mounted to the engine, and then measurements of the moment of momentary resistance to motion were performed. Also capturing phases of the engine work cycles in which the layer of nanotubes gives the best results seems to be possible. At present, long-term research is being carried out in order to determine the degree of the risk of exfoliation of the layer of CNT under the conditions of high mechanical and thermal loads.
\end{abstract}

Key words: combustion engine, friction losses, carbon nanotubes

\section{Wpływ zastosowania warstwy nanorurek węglowych na powierzchni nośnej tloka na straty tarcia}

W artykule przedstawiono wstępne wyniki badań oporów ruchu tłoków pokrytych warstwa nanorurek węglowych. Część opracowania poświęcono również problemom nakładania warstwy nanorurek na powierzchni stopu aluminium. Uzyskanie warstwy nanorurek o bardzo waskim polu tolerancji stanowiło trudny do rozwiazania problem technologiczny. Standardowy proces syntezy warstwy nanorurek prowadzi do korozyjnego uszkodzenia powierzchni bocznej tłoków, dlatego zostały opracowane nowe technologie pozwalajace uzyskać trwała warstwę nanorurek o grubości od kilkunastu do kilkudziesięciu mikrometrów. Tłoki o powierzchniach bocznych pokrytych warstwa nanorurek zamontowano do silnika o napędzie zewnętrznym, a następnie wykonano pomiary momentu chwilowych oporów ruchu, co umożliwia wskazanie tych faz cyklów pracy silnika, w których warstwa nanorurek daje największe korzyści. Obecnie prowadzone są dlugotrwate badania mające na celu wyeliminowanie niebezpieczeństwa zluszczania się warstwy nanorurek w warunkach dużego obciązenia mechanicznego i termicznego.

Słowa kluczowe: silnik spalinowy, straty tarcia, nanorurki węglowe

\section{Introduction}

Since the invention of the piston combustion engine there has been research aimed at improving the parameters of work as well as durability of engine sets. In particular, it is the stability of surfaces of collaborating sets that determines the durability of the engine. The most obvious sets which are of our concern are piston-cylinder groups, slide bearings of the crankshaft and timing gear systems. In principle, all surfaces moving against each other are enriched to some extent. Most frequently the surface refinement is in the form of hardening or applying a layer of chromium or other materials ensuring good frictional properties. For the last several years there has been a quick development of the possibilities of surface refinement by applying a layer of nanotubes.

Coating surfaces of alloys as well as ceramics with a layer of nanotubes is a difficult process, but the authors of this paper have gained quite a considerable experience of carrying out such procedures [2].

The authors assume to achieve tree main goals with the implementation of a layer of CNT on the piston bearing surface:

- reduction of friction losses,

- higher resistance to abrasive wear of mating elements,

\section{Wstęp}

Od czasu wynalezienia tłokowego silnika spalinowego prowadzone są działania zmierzające do poprawy parametrów jego pracy, a także trwałości zespołów silnika. O trwałości silnika decyduje wymiarowa i geometryczna niezmienność powierzchni współpracujących zespołów. Najbardziej oczywistymi zespołami, których ta uwaga dotyczy są: grupa tłokowo-cylindrowa, łożyska ślizgowe wału korbowego oraz układ rozrządu. W zasadzie wszystkie powierzchnie wzajemnie przemieszczające się są w jakimś stopniu uszlachetniane. Najczęściej uszlachetnianie powierzchni polega na hartowaniu lub nanoszeniu warstwy chromu albo innych materiałów, gwarantujących dobre właściwości tarciowe. Od kilku lat bardzo szybko rozwijają się metody uszlachetniania powierzchni przez nanoszenie warstw nanomateriałów, np. nanorurek węglowych.

Pokrywanie powierzchni stopów aluminium, a także ceramiki warstwą nanorurek jest procesem trudnym, ale autorzy niniejszego artykułu osiągnęli już pewne doświadczenie w przeprowadzaniu tego rodzaju działań [2].

Realizacja innowacyjnej koncepcji wykorzystania pokryć nanorurkowych na powierzchni bocznej tłoka może prowadzić do trzech zasadniczych efektów:

- zmniejszenia strat tarcia,

- zwiększenia odporności powierzchni na zużycie ścierne, 
- lower vibrations generated by the periodicity of a piston internal combustion engine cycle.

The specified goals do not have to occur simultaneously, and could also exclude themselves.

While achieving these goals, it is most important to develop the method of obtaining permanent, non-exfoliating layers of nanotubes bound to the base, that is the refined surface. Moreover, it is possible to embed an intermediate substance of good tribological properties, such as nanoparticles of platinum or molybdenum on the nanotubes surface.

\section{Carbon nanotubes synthesis}

The growth in the chemical vapor deposition process (CVD) allows to obtain Multiwalled Carbon Nanotubes (MWCNTs) on large surfaces, while achieving very good efficiency $[1,3,6,9,10,12,13]$.

Conducting the CNT growth process while using the CVD technique, at the simultaneous use of a strong electric field, enables vertical growth of nanotubes $[4,5,8,11]$. The vertical growth of nanotubes is shown in the Figure $1 \mathrm{~A}, 1 \mathrm{~B}$ and $1 \mathrm{C}$, whereas the anisotropic growth of CNT is shown in Figure 1D.

Figure 2 shows a piston selected for testing, before it was coated with a layer of nanotubes. The same piston after applying a layer of carbon nanotubes on the bearing surface is presented in Figure 3.
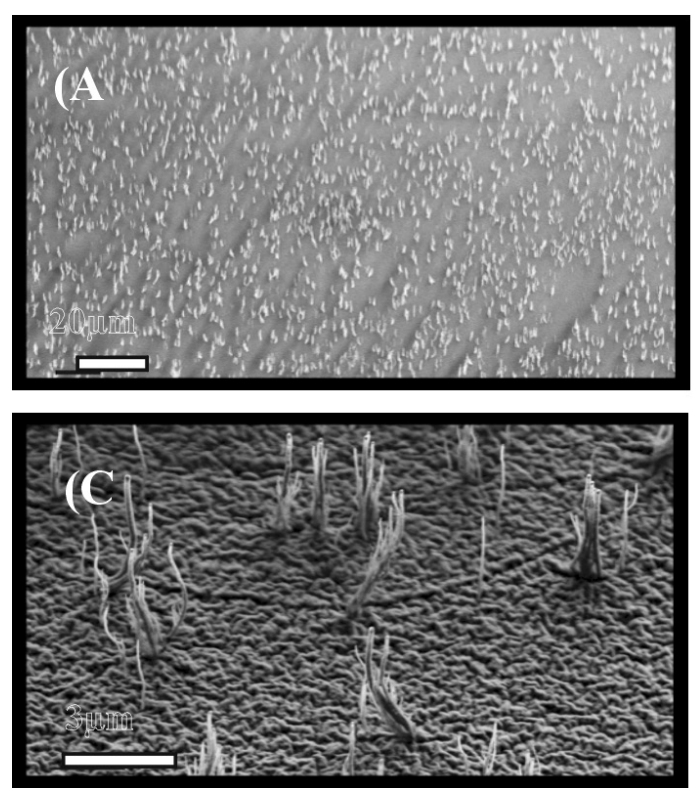

zmniejszenia drgań wywołanych cyklicznością pracy tłokowego silnika spalinowego,

przy czym efekty te nie muszą występować jednocześnie, lecz mogą się wręcz wzajemnie wykluczać.

Podstawą uzyskania tych efektów jest jednak opracowanie metody uzyskiwania niełuszczących się warstw nanorurek trwale związanych z podłożem, czyli uszlachetnianą powierzchnią. Na powierzchni nanorurkek może być dodatkowo osadzona substancja pośrednia o dobrych właściwościach tribologicznych; mogą to być między innymi nanocząstki platyny lub molibdenu.

\section{Synteza nanorurek}

Synteza nanorurek w procesie CVD (Chemical Vapor Deposition) umożliwia uzyskanie wielościennych nanorurek węglowych (MWCNT - Multiwalled Carbon Nanotubes) na dużych powierzchniach, przy jednoczesnym zapewnieniu bardzo dużej wydajności [1, 3, 6, 9, 10, 12, 13].

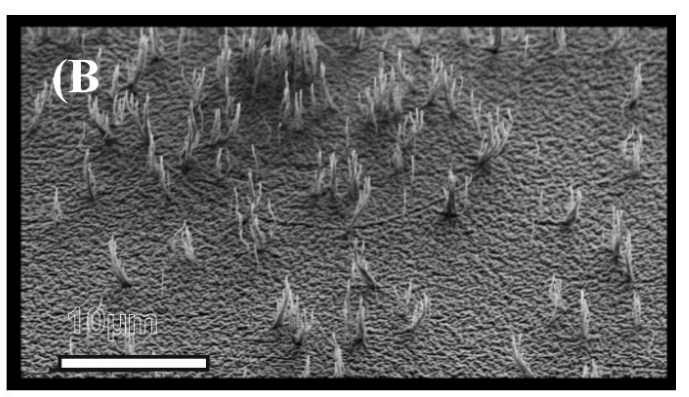

Fig. 1. Pictures from a scanning electron microscope (SEM) showing metal surface coated with CNTs [2] Rys. 1. Obrazy ze skaningowego mikroskopu elektronowego przedstawiajace powierzchnię metalowa pokryta nanorurkami węglowymi [2]

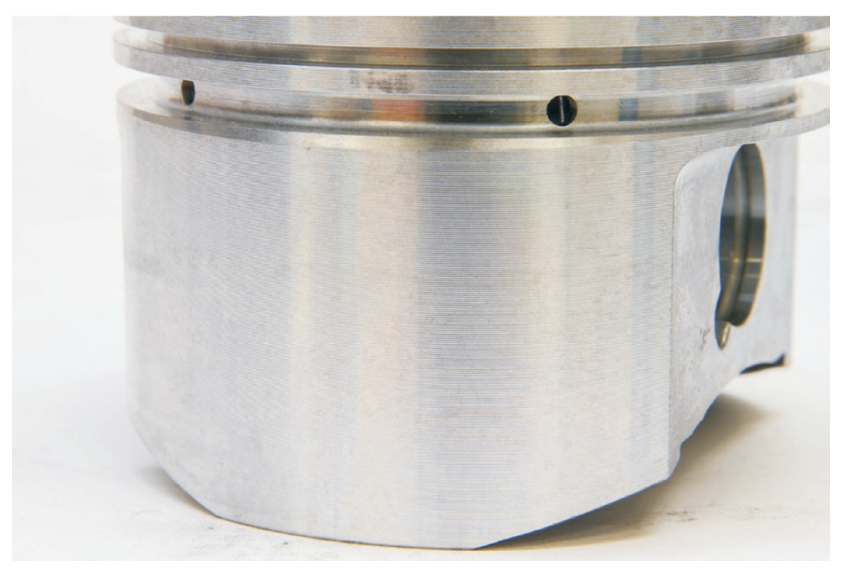

Fig. 2. Piston bearing surface before it was coated with CNT layer

Rys. 2. Powierzchnia nośna tłoka przeznaczonego do badań przed pokryciem warstwa nanorurek

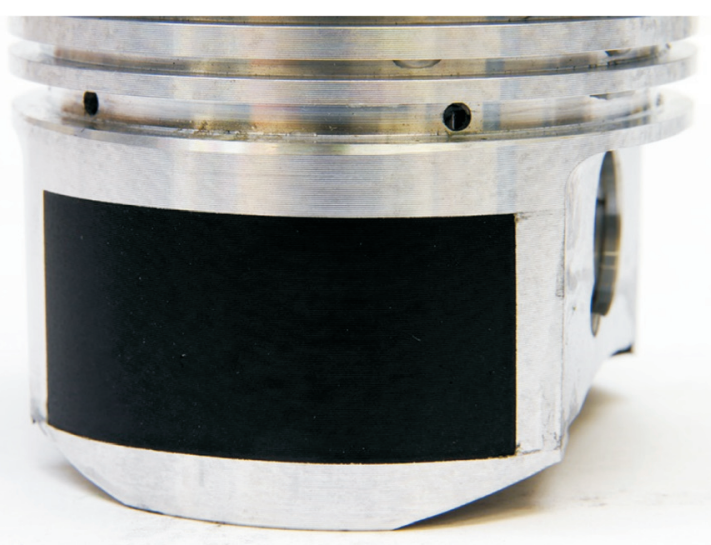

Fig. 3. Piston bearing surface after coating with CNT layer

Rys. 3. Powierzchnia nośna tłoka przeznaczonego do badań po pokryciu powierzchni bocznej warstwa nanorurek 


\section{Friction tests results of pistons with CTN coating}

The pistons presented in Figures 2 and 3 were mounted to the engine and then comparative tests of the resistance to motion torque were carried out. Test results for a factory piston are shown in Fig. 4, and for the piston coated with a layer of CNTs - in Figures 5,6 and 7. The tags are the same for all of the following figures. The blue line, which is associated with the scale on the left side of the figure, represents the direct signal measurements. The course of torque, which is corrected by subtracting the harmonics which are not in the phase with the engine speed, is represented by the green line. The torque which is subtracted from the measured torque signal is represented by the red line. The scale for the courses represented by the green and red lines is placed on the right side of the Figures.

The course of torque shown in Figure 5 was obtained after 5 minutes of engine motion, following its assembly, while the course in Figure 6 presents the measurement results after 15 minutes of engine motion, and finally the course in Figure 7 - after 25 minutes. The tests were performed while adopting the temperature of the cooling medium at the level of $80^{\circ} \mathrm{C}$. Figure 8 presents the test bench for the measurement of the coupling of the combustion engine with the electric motor that drives it.

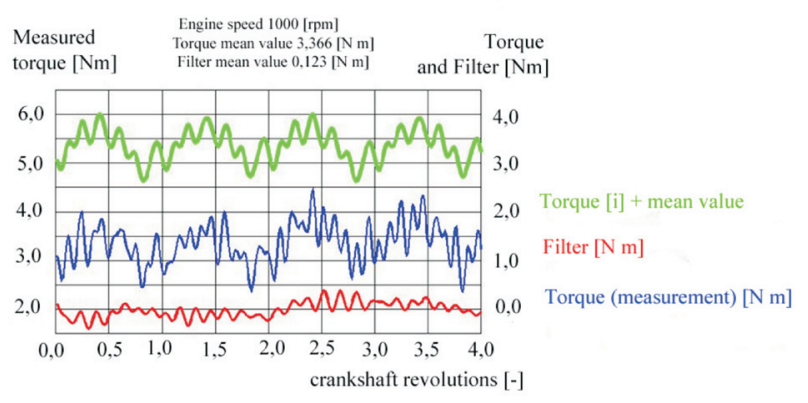

Fig. 4. The course of engine drive torque obtained for standard pistons after 10 hours of operation since its first run

Rys. 4. Przebieg momentu napędu silnika; przebiegi uzyskane dla ttoków standardowych po 10 godzinach pracy silnika

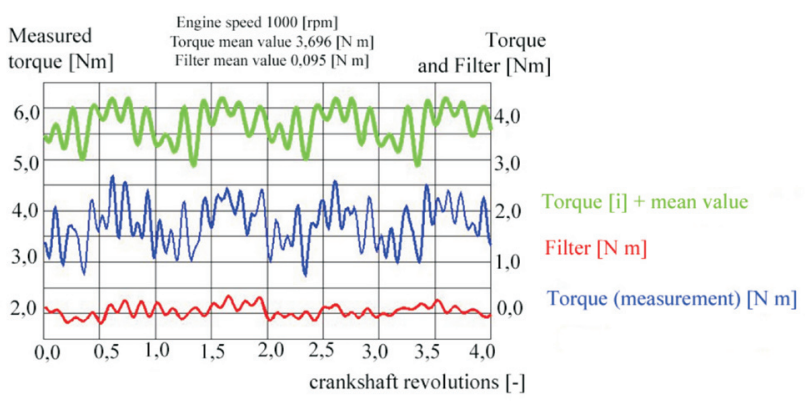

Fig. 6. The course of engine drive torque obtained for pistons with the CNT layer on the bearing surface after 15 minutes of engine operation since its first run

Rys. 6. Przebieg momentu napędu silnika; przebiegi uzyskane dla tłoków $z$ warstwa nanorurek po 15 minutach pracy silnika
Przeprowadzenie procesu syntezy CVD, przy jednoczesnym zastosowaniu silnego pola elektrycznego, pozwala na pionowy wzrost nanorurek $[4,5,8,11]$, który przedstawiono na rys. 1A, $\mathrm{B}, \mathrm{C}$, natomiast wzrost anizotropowy na rys. $1 \mathrm{D}$.

$\mathrm{Na}$ rysunku 2 przedstawiono tłok przeznaczony do badań przed pokryciem warstwą nanorurek, a na rys. 3 ten sam tłok po naniesieniu na powierzchni bocznej warstwy nanorurek.

\section{Wyniki badań momentu oporów ruchu silnika spalinowego z tlokami pokrytymi nanorurkami}

Tłoki przedstawione na rys. 2 i 3 zamontowano w silniku, a następnie przeprowadzono badania porównawcze momentu oporów ruchu. Wyniki pomiarów dla tłoka fabrycznego przedstawiono na rys. 4 , natomiast dla tłoka pokrytego warstwą nanorurek węglowych - na rys. 5, 6 i 7. Na wszystkich tych rysunkach oznaczenia poszczególnych przebiegów są takie same. Linia niebieska, skojarzona ze skalą naniesioną po lewej stronie wykresu, przedstawia wyniki pomiaru bezpośredniego. Przebieg momentu skorygowanego przez odjęcie od wyników pomiaru tych harmonicznych, które nie są w fazie z prędkością obrotową silnika oznaczony jest linią zielona, natomiast sumaryczny moment odjęty w wyniku korekcji od momentu zmierzonego pokazuje linia czerwona. Skala przebiegów naniesionych linią zieloną i czerwoną jest przedstawiona po prawej stronie rysunku.

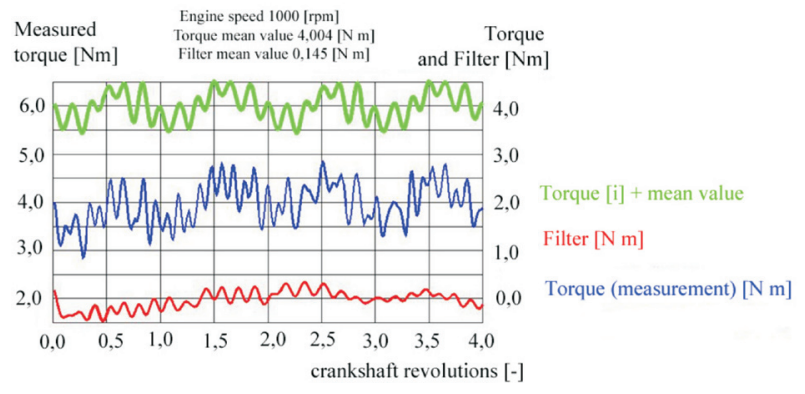

Fig. 5. The course of engine drive torque obtained for pistons with the CNT layer on the bearing surface after 5 minutes of engine operation since its first run

Rys. 5. Przebieg momentu napędu silnika; przebiegi uzyskane dla tłoków $z$ warstwa nanorurek po 5 minutach pracy silnika

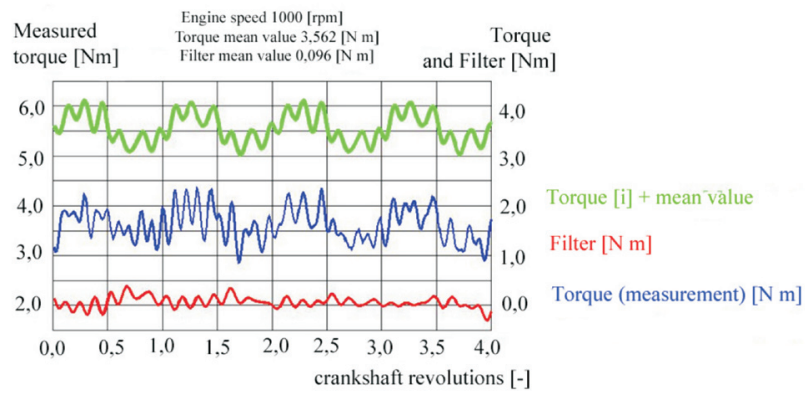

Fig. 7. The course of engine drive torque obtained for pistons with the CNT layer on the bearing surface after 25 minutes of engine operation since its first run

Rys. 7. Przebieg momentu napędu silnika; przebiegi uzyskane dla tłoków $z$ warstwa nanorurek po 25 minutach pracy silnika 


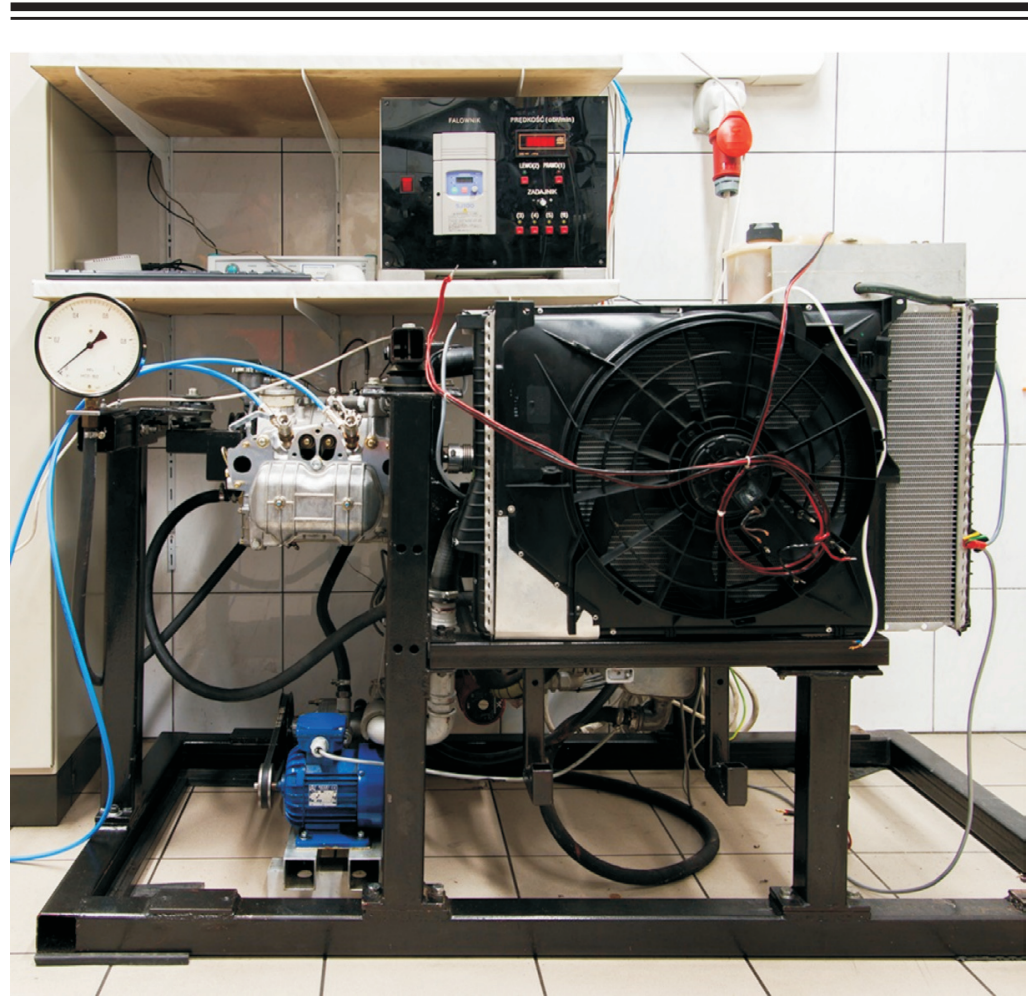

Fig. 8. General view on the test station for measuring the moment of coupling the internal combustion engine with the asynchronous electric motor that drives it

Rys. 8. Stanowiska do pomiaru momentu sprzężenia silnika spalinowego z napędzającym go asynchronicznym silnikiem elektrycznym

While building the test station, special attention was paid to ensure a stable temperature level of the cooling medium, which is necessary to capture the differences in internal frictional resistance generated by the tested engine for various pistons.

\section{Test results for pistons with improved CNT coating}

Results presented in the previous chapter were obtained for the first batch of pistons with an experimental CNT layer coating. After the short test run, which took about 50 minutes, the engine was dismantled and it revealed a high degree of CNT coating wear. It was decided to develop the next batch of pistons with an improved CNT coating. The process of coating was modified, therefore, the CNT layer was thinner and simultaneously better bound to the native material of the piston. After assembling the engine with the new batch of pistons, the test was performed. The test consisted of measuring the external drive torque with keeping the engine speed constant at $1000 \mathrm{rpm}$. The measurement was started right in the moment of the first engine run and was contin-
Przebiegi momentów przedstawione na rys. 5 uzyskano po 5 min od momentu uruchomieniu silnika $\mathrm{z}$ nowo zamontowanymi tłokami z warstwą nanorurek węglowych, przebiegi na rys. 6 przedstawiają wyniki pomiarów po $15 \mathrm{~min}$ i na rys. 7 po $25 \mathrm{~min}$. Badania przeprowadzono przy temperaturze oleju równej $80^{\circ} \mathrm{C}$. Stanowisko, na którym wykonano pomiary momentu sprzężenia silnika spalinowego z napędzającym go silnikiem elektrycznym przedstawiono na rys. 8 .

Budując stanowisko, szczególną uwagę zwrócono na zapewnienie stabilnej temperatury oleju smarującego, co jest konieczne w celu umożliwienia pomiaru różnic oporów tarcia silnika z różnymi wersjami tłoków.

\section{Wyniki badań momentu oporów ruchu silnika spalinowego $\mathrm{z}$ udoskonalonymi tlokami pokrytymi nanorurkami}

Przedstawione w rozdziale 3 wyniki badań uzyskano po zamontowaniu w silniku pierwszej partii tłoków eksperymentalnych pokrytych nanorurkami. Demontaż silnika przeprowadzony po wykonaniu krótkiej, kilkudziesięciuminutowej serii badań doprowadził do ujawnienia znacznego zużycia warstw nanorurek; dlatego podjęto decyzję o wykonaniu następnej, udoskonalonej partii tłoków. Dla tłoków udoskonalonych zmodyfikowano proces nanoszenia nanorurek, tak by uzy- 
ued for over 100 minutes. The oil temperature was kept at a steady level of $80^{\circ} \mathrm{C}$. The results obtained during that test run are presented in Figure 9.

After the first minute since the engine was started the torque value stabilized and for the rest of the test its variation did not exceed $0.1 \mathrm{~N} \cdot \mathrm{m}$. The variation of the mean value for ten minutes was less than $0.01 \mathrm{~N} \cdot \mathrm{m}$. The mean value for the total test duration was $3.18 \mathrm{~N} \cdot \mathrm{m}$ and this was less than for the test with standard pistons for which the mean torque value was $3.37 \mathrm{~N} \cdot \mathrm{m}$.

\section{The test results analysis}

By comparing the courses of torques of the combustion engine drive equipped with standard pistons and the ones coated with the layer of CNTs, one can notice the higher initial friction losses in the case of the pistons coated with CNTs, conventionally called SSNW. Following a 25-minute engine motion, the SSNW average engine moment of friction amounts to $3.56 \mathrm{~N} \cdot \mathrm{m}$, whereas the engine equipped with standard pistons $-\mathrm{SSTS}-3.36 \mathrm{~N} \cdot \mathrm{m}$. In the case of the SSNW engine, one can notice however, a clear tendency to decrease the moments of resistance to motion, and besides, the clearance between the piston and the cylinder bearing surface in the SSNW engines is less than the double value of the thickness of the nanotubes, that is $10 \mu \mathrm{m}$.

The more important result of the research is the mean deviation of the torque signal of the frequency different from the multiple frequency of the rotational motion defined as the non-periodical torque - NPT. The course of this signal is shown in figures 5 through 8 as red lines, where the values of the mean deviation are as follows:

- for the SSTS standard piston $-0.123 \mathrm{~N} \cdot \mathrm{m}$,

- for the SSNW piston after 5 minutes of engine work $0.145 \mathrm{~N} \cdot \mathrm{m}$,

- for the SSNW piston after 15 minutes of engine work $0.095 \mathrm{~N} \cdot \mathrm{m}$,

- for the SSNW piston after 25 minutes of engine work $0.096 \mathrm{~N} \cdot \mathrm{m}$.

The initial value of the mean NPT deviation for the SSNW pistons amounts to $0.145 \mathrm{~N} \cdot \mathrm{m}$, and next, it quickly decreases to the level of $0.095 \mathrm{~N} \cdot \mathrm{m}$; while for the SSTS pistons the value of the mean NPT deviation is $0.123 \mathrm{~N} \cdot \mathrm{m}$. This means that the SSNW pistons stabilize the motion of the piston, and this means less intense torsional vibrations and lower noise intensity.

The improvement of piston bearing surface coating process with a layer of CNT allowed to achieve less layer thickness whose adhesion was also improved. The application of upgraded coatings led to a reduction of the engine resistance to motion in comparison with the standard pistons without any coatings on the bearing surface.

\section{Conclusions}

1. There is a possibility of applying on the aluminum sidesurface of the piston a modified layer of CNTs of very small thickness, smaller than the standard assembly clearance of the pistons mounted in the cylinder. skać warstwę cieńsza, ale jednocześnie silniej związaną z materiałem rodzimym tłoka. Po zamontowaniu tych tłoków przeprowadzono eksperyment polegający na pomiarze momentu napędu zewnętrznego przy zachowaniu stałej, równej $1000 \mathrm{obr} / \mathrm{min}$ prędkości obrotowej. Pomiar rozpoczęto w chwili pierwszego uruchomienia silnika po montażu tłoków i kontynuowano w czasie kilkudziesięciu minut, przez cały czas eksperymentu utrzymywano stałą temperaturę oleju $80^{\circ} \mathrm{C}$. Otrzymane wyniki przedstawiono na wykresie rys. 9 .

Po pierwszej minucie od uruchomienia silnika wartość momentu obrotowego stabilizuje się i później jej wahania w poszczególnych pomiarach nie przekraczają $0,1 \mathrm{~N} \cdot \mathrm{m}$, wahania zaś średnich dziesięciominutowych są mniejsze niż $0,01 \mathrm{~N} \cdot \mathrm{m}$. Średnia wartość momentu napędu zewnętrznego, wyznaczona dla całego czasu eksperymentu, wynosi 3,18 N·m i jest to wartość mniejsza niż uzyskana w badaniach silnika z tłokami standardowymi $(3,37 \mathrm{~N} \cdot \mathrm{m})$.

\section{Analiza wyników badań}

Porównując przebiegi momentu oporów ruchu silnika spalinowego wyposażonego w tłoki standardowe i tłoki pokryte warstwą nanorurek węglowych, można zauważyć początkowo większe straty tarcia w odniesieniu do tłoków pokrytych nanorurkami węglowymi. Po 25 minutach ruchu silnika średni moment tarcia silnika $\mathrm{z}$ tłokami pokrytymi nanorurkami wynosi 3,56 $\mathrm{N} \cdot \mathrm{m}$, a silnika wyposażonego w tłoki standardowe $-3,37 \mathrm{~N} \cdot \mathrm{m}$. Dla silnika z tłokami pokrytymi nanorurkami można jednak zauważyć wyraźną tendencję zmniejszania się momentu oporów ruchu. Zmniejszanie oporów ruchu wynika prawdopodobnie z docierania warstwy nanorurek, zmniejszania jej grubości i w związku z tym zwiększania luzu tłoka w cylindrze, oraz ze zmniejszania chropowatości warstwy nanorurek.

Istotnym wynikiem badań jest średnie odchylenie sygnału momentu o częstotliwości różnej od wielokrotności częstotliwości ruchu obrotowego określanego dalej jako moment niecykliczny - MN. Przebieg tego sygnału przedstawiono na rys. 5-8 linią czerwoną, przy czym wartości średniego odchylenia wynoszą odpowiednio:

- dla tłoka standardowego - 0,123 N·m,

- dla tłoka pokrytego nanorurkami po 5 min pracy silnika $-0,145 \mathrm{~N} \cdot \mathrm{m}$,

- dla tłoka pokrytego nanorurkami po 15 min pracy silnika $-0,095 \mathrm{~N} \cdot \mathrm{m}$,

- dla tłoka pokrytego nanorurkami po 25 min pracy silnika $-0,096 \mathrm{~N} \cdot \mathrm{m}$.

Wartość początkowa średniego odchylenia MN dla tłoków pokrytych nanorurkami wynosi $0,145 \mathrm{~N} \cdot \mathrm{m}$, a następnie szybko zmniejsza się do 0,095 N·m, podczas gdy dla tłoków standardowych wartość średniego odchylenia MN wynosi $0,123 \mathrm{~N} \cdot \mathrm{m}$. Może to oznaczać, że wprowadzenie pokrycia tłoków stabilizuje ich ruch, a to prowadzi do mniej intensywnych drgań skrętnych wału korbowego silnika oraz mniejszego natężenia hałasu.

Udoskonalenie procesu nanoszenia nanorurek węglowych na powierzchnię boczną tłoka umożliwiło uzyskanie cieńszych warstw nanorurek, cechujących się większą adhezją. Zastosowanie takich tłoków prowadzi do zmniejszenia 
2. The developed layer of CNTs adheres to the aluminum surface to an extent preventing peeling of the layer due to both mechanical and thermal loads existing in the piston combustion engine driven from the outside.

3. A decrease in the clearance between the piston and the cylinder - by embedding a layer of nanotubes on the side surface of the piston - leads to a slight increase in the moment of resistance to motion, but these are the conditions limiting the torsional vibrations of the engine shaft.

4. The application of thin CNT layers on the piston bearing surface, which do not significantly reduce the pistoncylinder liner clearance, leads to the engine resistance to motion reduction which was measured for external drive conditions. oporów ruchu silnika w porównaniu do przypadku, gdy w silniku stosowane są tłoki standardowe.

\section{Wnioski}

1. Istnieje możliwość nanoszenia na aluminiową powierzchnię boczną tłoka zmodyfikowanej warstwy nanorurek węglowych o bardzo małych grubościach, mniejszych niż standardowy luz montażowy tłoków osadzonych w cylindrze.

2. Opracowana warstwa nanorurek węglowych przylega do powierzchni aluminiowej w stopniu zapobiegającym złuszczaniu się warstwy zarówno w wyniku obciążeń mechanicznych, jak i cieplnych panujących w tłokowym silniku spalinowym napędzanym z zewnątrz.

3. Zmniejszenie szczeliny między tłokiem a cylindrem przez osadzenie na powierzchni bocznej tłoka warstwy nanorurek prowadzi do ograniczenia drgań skrętnych wału korbowego.

4. Zastosowanie cienkich warstw nanorurek węglowych na powierzchni tłoka - nieograniczających znacznie luz tłoka w cylindrze - prowadzi do zmniejszenia oporów ruchu silnika zmierzonych w warunkach napędu zewnętrznego.

\section{Bibliography/Literatura}

[1] Arenz M., Mayrhofer K.J.J., Stamenkovic V., Blizanac B.B., Tomoyuki T., Ross P.N., Markovic N.M.J.: Am. Chem. Soc. 2005, 127, 6819-6829.

[2] Ciałkowski M., Iskra A., Giersig M., Kempa K: Wysokoefektywny samochodowy reaktor katalityczny na bazie trójwymiarowych hierarchicznych nanostruktur węglowych. Nr projektu: 3940/T02/2007/32, Poznań 2009.

[3] Cherstiouk O.V., Simonov P.A., Savinova E.R.: Electrochemistry Acta 2003, 48, 3851-3860.

[4] Durand R., Faure R., Gloaguen F., Aberdam D., Adzic R.R., Ansonand F.C., Kinoshita K.: The Electrochemical Society Inc., Pennington 1996, Vol. 95-26, p 27.

[5] Frelink T., Visscher W., van Veen J.A.R.: Journal of Electroanalytical Chemistry 382, 65-72 (1995).

[6] Kabbabi A., Gloaguen F., Andolfatto F., Durand R.: Journal of Electroanalytical Chemistry, 373, 251-254 (1994).

[7] Kałużny J.: Eksperymentalne zastosowania nanorurek weglowych w konstrukcji tłokowego silnika spalinowego. WPP, seria Rozprawy, nr 503, Poznań 2013.

[8] Kinoshita K.: Electrochemical oxygen technology, John Wiley \& Sons, New York 1992.
[9] Maillard F., Eikerling M., Cherstiouk O.V., Schreier S., Savinova E., Stimming U.: Faraday Discuss, 125 (2004) 357-377.

[10] Mukerjee S., McBreen J.J.: Electroanal. Chem. 1998, 448, 163-171.

[11] Sun Y., Zhuang L., Lu J., Hong X., Liu P.J.: Am. Chem. Soc. 2007, 129, 15465-15467.

[12] Takasu Y., Ohashi N., Zhang X. G., Murakami Y., Minagawa H., Sato S., Yahikozawa K.: Electrochimica Acta, 41, 25952600 (1996).

[13] Tang Z.C., Geng D.S., Lu G.X.J.: Colloid Interface Sci. 2005, 287, 159-166.

Prof. Antoni Iskra, Prof., DSc., DEng. - Professor in the Faculty of Machines and Transport at Poznan University of Technology.

Prof. dr hab. inż. Antoni Iskra - profesor na Wydziale Maszyn Roboczych i Transportu Politechniki Poznańskiej.

e-mail: antoni.iskra@put.poznan.pl

Maciej Babiak, DEng. - Doctor in the Faculty of Machines and Transport at Poznan University of Technology.

Dr inż. Maciej Babiak - adiunkt na Wydziale Maszyn Roboczych i Transportu Politechniki Poznańskiej. e-mail:maciej.babiak@put.poznan.pl
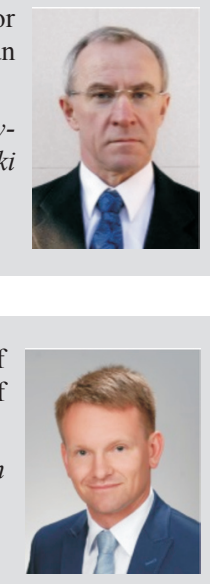

Jarosław Kałużny, DEng. - Doctor in the Faculty of Machines and Transport at Poznan University of Technology.

Dr inż. Jarosław Kałużny - adiunkt na Wydziale Maszyn Roboczych i Transportu Politechniki Poznańskiej.

e-mail: jaroslaw.kaluzny@put.poznan.pl

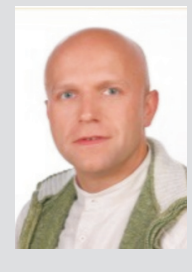

